\title{
Emotions, Persuasion, and Public Discourse in Classical Athens
}

Spatharas, Dimos (2019).

Berlín: De Gruyter. 234 pp. ISBN 978-3-11-061803-7.

\section{( Ariel Alejandro Palomo}

\section{Universidad Nacional del Sur, Argentina ariel2994@hotmail.com}

El campo de las emociones ha despertado, especialmente en los últimos diez años, el interés de la crítica en general, y del mundo clásico en particular. Sin embargo, la relación de la retórica con las emociones, aunque cuenta con algunas publicaciones destacadas, aún no ha atraído la atención que merece, por lo que este nuevo libro de Spatharas representa una adición importante a la escasa literatura sobre el tema.

El autor, profesor asociado en el Departamento de Filología Clásica de la Universidad de Creta, coedita la serie Trends in Classics: Ancient Emotions (De Gruyter), en la cual se inserta la presente publicación, y viene investigando de manera sostenida en el campo de la retórica antigua y la oratoria ática.

La línea de investigación desarrollada por Spatharas en los últimos años encuentra continuidad en este libro, en el cual se propone analizar los modos en que la retórica antigua producía efectos suasorios mediante la manipulación psicológica de los sentimientos de la audiencia. La obra consta de un breve prefacio y una introducción, en la que se exponen la metodología y los fundamentos teóricos. En primer lugar, el autor desafía la asunción convencional de que las emociones son impulsos irracionales, $y$ cuestiona tanto la tendencia a atender las emociones únicamente a partir de sus marcadores léxicos, como la búsqueda de equivalencias en lenguas modernas para los términos emocionales. Según Spatharas, esta aproximación no solo supone un reduccionismo de la compleja fenomenología de la emoción, en especial de la emoción en el mundo antiguo, sino que deja sin explicar el proceso que genera experiencias emotivas en el público.

Spatharas propone un abordaje mucho más enriquecedor: su análisis se fundamenta en un enfoque cognitivo orientado a las evaluaciones, inscribiéndose así en la línea de investigación inaugurada por David Konstan en The Emotions of the Ancient Greeks (2006. Toronto: University of Toronto Press). Por otra parte, se propone superar lo que él denomina un "enfoque logocéntrico" de la retórica, completando su investigación con el análisis de instancias no verbales de persuasión, especialmente aquellas ligadas a la visión. Esto último constituye uno de los temas de investigación más interesante y novedoso del libro, en la medida en que el análisis de las potencialidades afectivas de este órgano en la persuasión trasciende los límites de la crítica literaria y se proyecta en el estudio de las construcciones culturales alrededor de la ópsis.

A la introducción siguen cinco capítulos, en los que se aborda la relación entre las emociones y la persuasión en una variada gama de autores y géneros que van desde el discurso epidíctico de Gorgias, pasando por el histórico de Tucídides, hasta el retórico de los oradores áticos como Lisias, Demóstenes y Esquines. Estos capítulos, a su vez, pueden agruparse en dos secciones claramente diferenciadas: una que explora los vínculos entre éros, póthos y orgé con la visualidad, y otra que se centra exclusivamente en el rol de la envidia (phthónos) en los discursos forenses y en los segmentos de periautología presentes en ellos.

En el primer capítulo, el autor indaga las relaciones establecidas por Gorgias entre la visión y el lógos con las emociones en El encomio de Helena. Spatharas destaca aquí la pasividad que el sofista asigna a las personas frente a las imágenes externas captadas por el ojo: estas se imprimen en la psyché o phrén del espectador y generan emociones dañinas para el raciocinio, las cuales derivan en actos inmorales. Esta cualidad psicotrópica de la visión, observa Spatharas, también se encuentra presente en la disertación sobre el poder del lógos. Con ello, el autor señala que Gorgias logra representar a Helena de una manera novedosa, esto es, como una víctima pasiva de la influencia erótica de la belleza y las palabras de Paris. Para Spatharas, este poder atribuido a la visión y el logos responde a la apropiación de la teoría materialista de Demócrito, especialmente de los postulados sobre los eídola. Si bien esta hipótesis es 
atractiva, resulta difícilmente comprobable-como él mismo lo reconoce-debido a la fragmentariedad de la obra del filósofo atomista. Además, afirma que este modelo ‘científico' utilizado por Gorgias pretendía refutar una concepción tradicional de la visión y deslumbrar al auditorio con un enfoque novedoso, punto que resulta igualmente difícil de constatar (como el autor también reconoce), porque, además, ¿hasta qué punto se puede diferenciar la supuesta cientificidad de Demócrito de las creencias populares, a partir de las parcas fuentes indirectas? Spatharas, por otro lado, tampoco diferencia claramente estos dos modelos; más aún, él mismo reconoce, al inicio del capítulo, que ambos construían la ópsis como un sentido háptico y una fuente potencial de cambios psicofísicos y emocionales indeseables.

En el siguiente capítulo, Spatharas realiza un interesante análisis de la implicancia de la ópsis en la fenomenología de éros, póthos y orgé en Tucídides, discusión que complementa algunas de las conclusiones alcanzadas en el capítulo anterior. En primer lugar, examina el famoso discurso fúnebre de Pericles, en el cual advierte que el estratego, consciente de la inferior potencia afectiva del lógos frente a la ópsis, construye un discurso que coloca en primer plano la belleza de Atenas. Spatharas concluye que Pericles explota la capacidad erótica de la visión para crear en el público un compromiso pasional y recíproco con esta ciudad. Luego, contrasta la retórica visual de Pericles con las consecuencias nefastas de la ópsis en los discursos de Nicias y Alcibíades. Este último presume de los méritos propios para demostrar su idoneidad como líder de la expedición a Sicilia, y su exhibición de poder personal da una falsa impresión de que la ciudad está adecuadamente preparada. De este modo, puntualiza Spatharas, se genera un desplazamiento del éros por Atenas, promocionado por Pericles, hacia las lejanas tierras sicilianas. El autor, a continuación, analiza el infructuoso intento de disuasión de Nicias, y señala que la vívida descripción de la isla, en su segundo discurso, transforma el éros por la campaña en un dýseros, es decir, una forma malsana de esta pasión. Por último, Spatharas explora los vínculos entre la visión y la ira en el discurso de Arquidamo en la víspera de la invasión del Ática, y sugiere que la representación de la ira como una fuerza externa que ataca al espectador, impulsándolo a actuar irreflexivamente, revela la influencia del modelo afectivo de la visión elaborado por Gorgias. Esta hipótesis, sin embargo, parece ignorar las conclusiones alcanzadas por Ruth Padel en In and Out of the Mind (1992. Princeton: Princeton University Press), quien observó que la imagen de la emoción como una fuerza disruptiva que ingresa en el cuerpo a través de los póroi puede rastrearse hasta Homero. Si bien esta autora forma parte del índice bibliográfico del libro, sorprende la falta de integración de sus valiosos aportes en el análisis de las emociones de Spatharas.

A continuación, nos encontramos con el capítulo tercero, el más extenso y sugerente del libro, que realiza un aporte significativo al campo interdisciplinar de la retórica y las emociones, examinando la noción de enárgeia y su relación con la visión y la pathopoiía en la narrativa forense. En este punto, Spatharas retoma sus postulados de estudios previos, según los cuales los discursos forenses contextualizaban las disputas legales en un trasfondo social más amplio ("Kinky stories from the rostrum: storytelling in Apollodorus' Against Neaira" (2009), Ancient Narrative 9, 99-120). Esto le sirve de marco para sostener que los oradores lograban la persuasión, induciendo respuestas emocionales estereotipadas mediante narrativas que apelaban a creencias ideológicas compartidas. La visión, para Spatharas, cumplía un papel determinante en este proceso, aunque de una manera diferente a la performatividad estudiada usualmente por la crítica: estos elementos, culturalmente significativos, evocaban imágenes mentales familiares en los espectadores, de modo de activar su phantasía e inmiscuirlos activamente en el mundo narrativo. El estudioso, entonces, procede a demostrar estas conclusiones en discursos seleccionados de Lisias, Demóstenes y Esquines, y revelar los guiones emocionales usados para incitar en el jurado ira hacia el adversario y compasión por el querellante.

A la luz de estos señalamientos, Spatharas revisa, en el capítulo cuatro, sus teorías previas sobre la envidia, y reinterpreta el lujo de Midias en Demóstenes (The Theatre ofJustice. 2017. Leiden: Brill), explorando los usos forenses de la misma para la persuasión y sus procesos de resignificación según los distintos usos ideológicos. Observa que, en principio, el uso retórico de esta emoción estaba ligado a un discurso antidemocrático, en el que las élites imputaban sentimientos de envidia a la masa de ciudadanos para deslegitimizar sus reclamos igualitarios. Sin embargo, Spatharas indica que el término phthónos en los discursos democráticos adquiere un significado equivalente a la descripción aristotélica de ‘indignación' (tò nemesân). Demóstenes, señala el autor, busca despertar esta forma de 'envidia legítima' atribuyendo a Midias comportamientos disruptivos con los valores cooperativos de la ideología democrática. Por lo tanto, concluye que esta resignificación devino un mecanismo para controlar la philotimía de los ricos y regular las inequidades sociales. 
En el quinto y último capítulo, retoma su anterior análisis sobre la periautología retórica ("Self-Praise and Envy: from Rhetoric to Athenian Courts" (2011), Arethusa 44.2, 199-219), y sostiene que era una práctica desaconsejada, porque comprometía la autoestima del oyente y suscitaba su envidia, lo cual individualizaba y aislaba al orador de la masa deliberante que intentaba manipular. Por ello, indica Spatharas, se desplegaban usualmente dos estrategias discursivas para mitigar la envidia: por un lado, resaltar la desgracia personal, y por el otro, hacer partícipe al auditorio de los méritos ostentados. De este modo, concluye que los oradores demostraban su adherencia a los valores cooperativos de la ideología democrática y establecían las condiciones necesarias para despertar la compasión por su infortunio.

El libro cierra con un breve epílogo y cuenta, naturalmente, con un apartado bibliográfico amplio y actualizado y con dos índices: uno para términos y autores contemporáneos, y otro para autores antiguos y pasajes relacionados con la discusión de la publicación. Por todo esto, la obra resultará de sumo interés para todo interesado en el campo de la retórica y las emociones, no solo para la crítica especializada, sino también para un público de intereses más heterogéneos. 